\title{
FLORISTIC AND GEOBOTANIC FEATURES OF THE RENATURALIZATION PROCESS OF UST'-SOKSKIY QUARRY
}

(C) 2016

N.V. Prokhorova, doctor of biological sciences, professor of Ecology, Botany and Nature Protection Department

Yu.V. Makarova, candidate of biological sciences, assistant of Ecology, Botany and Nature Protection Department Samara National Research University, Samara (Russia)

A.A. Golovlyov, doctor of geographical sciences, professor of World Economy Department Samara State University of Economics, Samara (Russia)

M.V. Samykina, postgraduate student of Ecology, Botany and Nature Protection Department

A.M. Pankevich, student of Biology Faculty

Samara National Research University, Samara (Russia)

Abstract. Studies devoted to artificial reclamation and natural renaturalization of the open cuts are important because of the distribution of the nonmetallic open-cut mining in the Middle Volga. The following article contains the results of floristic and geobotanical study of the Ust'-Sokskiy quarry, where the secondary plantation has been forming for the last 40 years after calciferous stock mining and quarrying. At present overgrowing Ust'-Sokskiy quarry is used as a natural testing field for exploration of the secondary anthropogenic successions, ecological, anatomical, morphological, physiological, biochemical and biogeochemical peculiarities of plants. 107 species of the vascular plants belonging to 83 genera, 35 families, 5 classes and 4 phyla were fixed in the quarry. 6 species from the Red Book of Samara Region were found in the composition of the local flora. Species penetration to the quarry is realized by dissemination from the nearest natural phytocenoses of Sokolii Mountains. Local flora of the quarry is significantly poorer than that of the Sokolii Mountains and differed by species composition that is explained by abiotic conditions specifics which are inherent to the technologically disturbed territory. Herbaceous and woody plants of the quarry are characterized by depressed vital condition. Modern local flora of the quarry is unbalanced and the process of its forming is continued.

Keywords: Sokolii Mountains; Ust'-Sokskiy quarry; calciferous rocks; local flora; floristic specters; phytodiversity; floristic and geobotanical analysis; renaturalization; overgrowth; life forms; ecobiomorphic analysis; coenomorphs; trophomorphs; hygromorphs; heliomorphs; anthropogenic succession.

УДК $502.4(470.43)$

\section{ЭКОЛОГО-ТУРИСТИЧЕСКИЙ ПОТЕНЦИАЛ САМАРСКОЙ ОБЛАСТИ: РЕСУРСЫ РАСТИТЕЛЬНОГО МИРА}

(C) 2016

С.В. Саксонов, доктор биологических наук, профессор,

заведующий лабораторией проблем фиторазнообразия, заместитель директора по научной работе

А.Г. Розенберг, кандидат биологических наук, младший научный сотрудник группы экономики природопользования

С.А. Сенатор, кандидат биологических наук, старший научный сотрудник лаборатории проблем фиторазнообразия

Институт экологии Волжского бассейна РАН, Тольятти (Россия)

И.В. Казанцев, кандидат биологических наук, декан естественно-географического факультета, доцент кафедры химии, географии и методики их преподавания

Самарский государственный социально-педагогический университет, Самара (Россия)

B.М. Васюков, кандидат биологических наук, научный сотрудник лаборатории проблем фиторазнообразия Институт экологии Волжсккого бассейна РАН, Тольятти (Россия)

Аннотация. В статье рассматривается развитие экологического туризма, которое, прежде всего, базируется на посещении привлекательных и уникальных объектов. В полной мере этим требованиям соответствует растительный мир. Впервые сформулировано 10 оснований, стимулирующих развитие познавательного экологического туризма (видовое разнообразие, реликтовые виды; эндемичные виды; виды, описанные с территории региона впервые для науки; растения, признанные охраняемыми и занесенные в Красную книгу; растительные сообщества, уникальные по происхождению и составу; зональные, типичные растительные сообщества; места концентрации растений на территории памятников природы; особо ценные природные территории федерального уровня охраны; ключевые ботанические территории) и 5 оснований, стимулирующих развитие событийного экологического туризма (даты рождения исследователей; даты проведения экспедиций; даты организации центров по изучению растительного мира; даты публикации важнейших ботанических сочинений; даты проведения крупнейших научных форумов). Описывается концентрация памятников природы и распределение особо охраняемых природных территорий в пределах Самарской области. В статье используется обобщенный критерий оценки фитосозологического статуса данных территорий. Отмечается, что Самарская область является перспективной территорией для развития внутреннего туризма, где важная и определяющая роль принадлежит экологическому туризму.

Ключевые слова: особо охраняемые природные территории; памятники природы; экологический туризм; познавательный туризм; событийный туризм; видовое разнообразие; растительные сообщества; растительный мир; реликты; эндемики; редкие растения; Красная книга; Самарская область. 
Саксонов С.В., Розенберг А.Г., Сенатор С.А., Казанцев И.В., Васюков В.М.

Несмотря на то, что Самарская область относится к регионам Среднего Поволжья с высокой степенью преобразованности ландшафтов, ее природно-ресурсный потенциал огромен и заслуживает внимания как объект, способствующий развитию познавательного туризма. Особенно привлекателен растительный покров региона, отличающийся большой мозаичностью, разнообразием и сравнительно высокой фрагментарной сохранностью.

В пользу особой привлекательности для использования растительных ресурсов в целях познавательного и событийного экологического труизма свидетельствуют следующие характеристики. Ниже мы приводим 10 обоснований, представляющих для экологического туризма (включая экспедиции, однодневные и многодневные экскурсии, полевые семинары, школьные и студенческие практики и т.д.), которые помогут организаторам туризма познакомить желающих с уникальными представителями флоры и растительного мира Самарской области, сопровождая их литературными ссылками в целях подготовки экскурсоводов и гидов (руководителей).

1.1. Флористическое разнообразие, оцениваемое порядком около 2000 видов, включая следующие генетические группы - аборигены, адвенты и культивируемые [1], т.е. «есть на что посмотреть».

1.2. Наличие большой группы сохранившихся реликтовых растений, представляющих различные этапы исторического развития флоры [2-5].
1.3. Наличие большой группы эндемичных видов (включая узкоэндемичные), подчеркивающих самобытность самарской флоры $[6,7]$, т.е. «только у нас, и более нигде».

1.4. Наличие группы видов, описанных впервые для науки с территории Самарской области [1, 8-10], т.е. «ботанические эталоны».

1.5. Растения, включенные в Красную книгу Самарской области - 258 цветковых, 4 - голосеменных, 3 - плаунообразных 2 - хвощевидных, 14 - папоротникообразных, 6 - моховидных, 7 - лишайников, 8 водорослей и 4 - грибов [10-12], т.е. «они могут исчезнуть, знай и сохраняй».

1.6. Растительные сообщества, уникальные по своему генезису, составу и не имеющие мировых аналогов, как реликтовые толокнянковые боры и сообщества скальных обнажений [13-15] и реликтовые растительные сообщества, отражающие геологическую историю развития территории - болотные комплексы [16-18], т.е. «свидетели тысячелетней естественной истории».

1.7. Зональные сообщества, формирующие облик ландшафтов Самарской области - степи и леса [15], т.е. «вижу чудное приволье».

1.8. Группа памятников природы регионального значения, как места сосредоточения представителей флоры и ценных растительных сообществ с максимальной их сохранностью [19-24], или «пешком по Самарскому краю» (табл. 1).

Таблица 1 - Доля памятников природы регионального значения в земельном фонде Самарской области и их природоохранный рейтинг

\begin{tabular}{|c|c|c|c|c|c|c|}
\hline \multirow{2}{*}{$\begin{array}{l}\text { № } \\
\Pi / \Pi\end{array}$} & \multirow{2}{*}{$\begin{array}{c}\text { Муниципальный } \\
\text { район }\end{array}$} & \multicolumn{2}{|c|}{ Площадь, км² } & \multicolumn{2}{|c|}{ ООПТ } & \multirow{2}{*}{$\begin{array}{c}\text { Средний балл } \\
\text { рейтинга ООПТ }\end{array}$} \\
\hline & & Район & ООПТ & Общее число & $\begin{array}{c}\text { Доля от площа- } \\
\text { ди района, \% }\end{array}$ & \\
\hline 1 & Алексеевский & 1890 & 7,35 & 10 & 0,4 & 70,4 \\
\hline 2 & Безенчукский & 1988,8 & 87 & 7 & 4,4 & 81,5 \\
\hline 3 & Богатовский & 824 & 4,3 & 4 & 0,5 & 96,3 \\
\hline 4 & Большеглушицкий & 2534 & 10 & 4 & 0,4 & 83,3 \\
\hline 5 & Большечерниговский & 2980 & 88,2 & 9 & 2,9 & 122,9 \\
\hline 6 & Борский & 2103 & 1 & 5 & 0,05 & 71,1 \\
\hline 7 & Волжский & 2481 & 91,7 & 13 & 3,7 & 58,2 \\
\hline 8 & Елховский & 1201 & 2,5 & 5 & 0,2 & 79,2 \\
\hline 9 & Исаклинский & 1578 & 7,5 & 8 & 0,4 & 89,5 \\
\hline 10 & Камышлинский & 823,5 & 20,1 & 10 & 2,4 & 56,3 \\
\hline 11 & Кинельский & 2103,7 & 15,5 & 12 & 0,7 & 36,6 \\
\hline 12 & Кинель-Черкасский & 2469 & 12 & 7 & 0,5 & 144 \\
\hline 13 & Клявлинский & 1160 & 3,3 & 5 & 0,3 & 53,4 \\
\hline 14 & Кошкинский & 1750 & 16,3 & 2 & 0,9 & 110,5 \\
\hline 15 & Красноармейский & 2190 & 4,5 & 5 & 0,2 & 79,2 \\
\hline 16 & Красноярский & 2310 & 20,8 & 8 & 0,9 & 83,5 \\
\hline 17 & Нефтегорский & 1350 & 7,8 & 8 & 0,6 & 66,5 \\
\hline 18 & Пестравский & 1960 & 35,4 & 6 & 1,8 & 98,2 \\
\hline 19 & Похвистневский & 2130 & 61,6 & 9 & 2,9 & 101,1 \\
\hline 20 & Приволжский & 1379,3 & 6,2 & 7 & 0,5 & 54,3 \\
\hline 21 & Сергиевский & 2720 & 9,8 & 9 & 0,3 & 82,4 \\
\hline 22 & Ставропольский & 3662 & 22,6 & 2 & 0,6 & 74,5 \\
\hline 23 & Сызранский & 1887 & 107,6 & 15 & 5,7 & 100,5 \\
\hline 24 & Хворостянский & 1845 & 2,5 & 7 & 0,1 & 56,4 \\
\hline 25 & Челно-Вершинский & 1162 & 23,6 & 6 & 2 & 70,3 \\
\hline 26 & Шенталинский & 1338,2 & 16,6 & 7 & 1,2 & 63,8 \\
\hline 27 & Шигонский & 2134,4 & 75,2 & 11 & 3,5 & 115 \\
\hline 28 & г.о. Самара & 541,382 & 7,8 & 6 & 1,4 & 53,5 \\
\hline 29 & г.о. Сызрань & 117 & 2,7 & 6 & 2,3 & 18,6 \\
\hline 30 & г.о. Тольятти & 314,78 & 8,6 & 1 & 2,7 & 87 \\
\hline & Итого & 52927,06 & 780,05 & 214 & 1,4 & 77,59 \\
\hline
\end{tabular}


Наибольшая концентрация памятников природы в Сызранском - 15 ООПТ, Волжском - 13, Кинельском - 12, Шигонском - 11, Алексеевском и Камышлинском - по 10 в каждом муниципальном районе. Распределение ООПТ по доле занимаемых площадей от общей площади муниципального района выглядит иным образом. В среднем по всем муниципальным районам она составляет $1,4 \%$ и лишь в 11 районах (включая городские округа Сызрань и Тольятти) площадь под ООПТ выше средней (табл. 1), достигая своих максимальных значений в Сызранском $(5,7 \%)$ и Безенчукском (4,4\%) муниципальных районах.

Используя обобщенный критерий оценки фитосозологического статуса [23] получаем распределение муниципальных районов по рейтингу (в баллах). Наиболее привлекательными с позиции организации экологического туризма являются следующие муниципальные районы: Кинель-Черкасский - 144; Большечерниговский - 122,9; Шигонский - 115; Кошкинский - 110,5; Похвистневский - 101,1; Сызранский 100,5 ; Пестравский - 98,2; Богатовский - 96,3; Исаклинский $-89,5$; г.о. Тольятти - 87; Красноярский 83,5 ; Большеглушицкий - 83,3; Сергиевский - 82,4; Безенчукский - 81,5; Елховский - 79,2; Красноармейский - 79,2 (близ среднего значения). Ниже среднего значения (по баллам рейтинга) следующие административные районы: Ставропольский - 74,5; Борский - 71,1; Алексеевский - 70,4; Челно-Вершинский 70,3; Нефтегорский - 66,5; Шенталинский - 63,8; Волжский - 58,2; Хворостянский - 56,4; Камышлинский - 56,3; Приволжский - 54,3; г.о. Самара - 53,5; Клявлинский - 53,4; Кинельский - 36,6; г.о. Сызрань - 18,6. Однако, перечисленные муниципальные районы, имеющие рейтинг «ниже среднего», имеют свои ценности, которые необходимо также учитывать при планировании познавательного экологического туризма.

Ниже перечислены особо охраняемые природные территории Самарской области, характеризующиеся максимальной привлекательностью для развития познавательного экологического туризма (табл. 2).

1.9. Особо охраняемые природные территории федерального значения, крупные природно-территориальные комплексы: Жигулевский государственный биосферный заповедник им. И.И. Спрыгина и национальный парк «Самарская Лука», объединенные в Средне-Волжский комплексный биосферный резерват, национальный парк «Бузулукский бор» [5; 25], или «заповедный напев, заповедная даль».

1.10. Ключевые ботанические территории, крупные природно-территориальные комплексы, неохваченные (или частично охваченные) природоохранным режимом, отражающие уникальное сочетание ландшафтного и флористического разнообразия [26; 27], или «для нас и наших потомков».

Привлекателен и событийный экологический туризм. Богатейшая история изучения растительного покрова Самарской области, развития природоохранного дела связана с именами выдающихся естествоиспытателей, а также рядом событий, которые, несомненно, могут привлечь внимание туриста и краеведа, интересующегося не только природой, но и ее познанием. К сожалению, источников по экологическому событийном туризму в Самарской области слишком мало [28-31], но даже они показывают огромный диапазон тем и направлений организации событийного туризма.

Таблица 2 - Рейтинг памятников природы Самарской области по критерию привлекательности для развития познавательного туризма

\begin{tabular}{|c|c|c|c|}
\hline $\begin{array}{l}\text { Рей- } \\
\text { тинг }\end{array}$ & $\begin{array}{c}\text { Бал } \\
\text { лы }\end{array}$ & ООПТ & $\begin{array}{c}\text { Муниц. } \\
\text { район } \\
\text { (обозн. в } \\
\text { табл. 1) }\end{array}$ \\
\hline $1-2$ & 150 & Рачейская тайга & 23 \\
\hline $1-2$ & 150 & Гурьев овраг & 27 \\
\hline 3 & 147 & Озеро Молочка & 9 \\
\hline 4 & 144 & \begin{tabular}{|l|} 
ррызлы - \\
опустыненная степь
\end{tabular} & 5 \\
\hline $5-6$ & 143 & $\begin{array}{l}\text { Меловые леса южной части } \\
\text { Сенгилеевской } \\
\text { возвышенности }\end{array}$ & 27 \\
\hline $5-6$ & 143 & Муранский бор & 27 \\
\hline 7 & 140 & Левашовская лесостепь & 27 \\
\hline 8 & 139 & Балка Кладовая & 5 \\
\hline 9 & 138 & Серноводский шихан & 21 \\
\hline 10 & 137 & Подвальские террасы & 27 \\
\hline $11-13$ & 136 & Истоки реки Большой Иргиз & 5 \\
\hline $11-13$ & 136 & Муранские брусничники & 27 \\
\hline $11-13$ & 136 & Муранские озера & 27 \\
\hline $13-14$ & 135 & Рачейский бор & 23 \\
\hline $13-14$ & 135 & Моховое болото & 23 \\
\hline $15-16$ & 131 & Гора Копейка & 19 \\
\hline $15-16$ & 131 & Семь ключей & 23 \\
\hline $17-20$ & 130 & Каменные лога № 1, 2, 3 & 5 \\
\hline $17-20$ & 130 & Гора Зеленая & 8 \\
\hline $17-20$ & 130 & $\begin{array}{l}\text { Исаклинская } \\
\text { нагорная лесостепь }\end{array}$ & 9 \\
\hline $17-20$ & 130 & Раменская лесная дача & 23 \\
\hline 21 & 127 & Гора Лысая & 8 \\
\hline $22-13$ & 126 & Майтуганские солонцы & 2 \\
\hline $22-23$ & 126 & Гора Каратал чагыл & 10 \\
\hline 24 & 125 & $\begin{array}{l}\text { Ульяновско-Байтуганское } \\
\text { междуречье }\end{array}$ & 10 \\
\hline 25 & 124 & Узилово болото & 23 \\
\hline $26-28$ & 123 & Кошкинская балка & 5 \\
\hline $26-28$ & 123 & Урочище Мулин Дол & 5 \\
\hline $26-28$ & 123 & Гипновое болото & 14 \\
\hline 29 & 122 & Гора Высокая & 21 \\
\hline $30-31$ & 121 & Попов сад & 4 \\
\hline $30-31$ & 121 & Иргизская пойма & 18 \\
\hline $32-33$ & 119 & Красносамарский сосняк & 11 \\
\hline $32-33$ & 119 & Чубовская степь & 11 \\
\hline 34 & 118 & Рачейские скалы & 23 \\
\hline $35-37$ & 117 & Кутулукские яры & 3 \\
\hline $35-37$ & 117 & Гостевский шихан & 6 \\
\hline $35-37$ & 117 & $\begin{array}{l}\text { Сокольи горы и берег } \\
\text { между Студеным } \\
\text { и Коптевым оврагами } \\
\end{array}$ & 28 \\
\hline 38 & 116 & Сестринские окаменелости & 5 \\
\hline $39-42$ & 114 & Каменный дол & 11 \\
\hline $39-42$ & 114 & Гора Красная & 16 \\
\hline
\end{tabular}




\begin{tabular}{|c|c|c|c|}
\hline $39-42$ & 114 & Гора Лысая & 16 \\
\hline $39-42$ & 114 & Домашкинская лесостепь & 17 \\
\hline 43 & 112 & Овраг Верховой & 11 \\
\hline $44-46$ & 111 & Царев курган & 16 \\
\hline $44-46$ & 111 & Абдулзаводская дубрава & 19 \\
\hline $44-46$ & 111 & $\begin{array}{l}\text { Ятманские } \\
\text { широколиственные леса }\end{array}$ & 19 \\
\hline $47-48$ & 110 & $\begin{array}{l}\text { Лесостепь } \\
\text { в верховьях р. Аманак }\end{array}$ & 19 \\
\hline $47-48$ & 110 & Горы на реке Казачка & 21 \\
\hline $49-50$ & 109 & Вязовская ковыльная степь & 17 \\
\hline $49-50$ & 109 & $\begin{array}{l}\text { Малоусинские нагорные } \\
\text { сосняки и дубравы }\end{array}$ & 23 \\
\hline $51-53$ & 108 & Березовый овраг & 1 \\
\hline $51-53$ & 108 & Озеро Солодовка & 9 \\
\hline $51-53$ & 108 & $\begin{array}{l}\text { Алакаевско-Чубовская } \\
\text { каменистая степь }\end{array}$ & 11 \\
\hline $54-57$ & 106 & Истоки р. Каралык & 4 \\
\hline $54-57$ & 106 & $\begin{array}{l}\text { Прибайкальская } \\
\text { настоящая степь }\end{array}$ & 15 \\
\hline $54-57$ & 106 & $\begin{array}{l}\text { Подбельские } \\
\text { пойменные дубравы }\end{array}$ & 19 \\
\hline $54-57$ & 106 & $\begin{array}{l}\text { Похвистневские } \\
\text { пригородные дубравы }\end{array}$ & 19 \\
\hline $58-59$ & 104 & Орлиная пещера & 27 \\
\hline $58-59$ & 104 & Чувашский бугор & 27 \\
\hline $60-62$ & 103 & $\begin{array}{l}\text { Участок типчаково- } \\
\text { ковыльной целинной степи }\end{array}$ & 5 \\
\hline $60-62$ & 103 & $\begin{array}{l}\text { Ландшафтный комплекс } \\
\text { вдоль р. Малый Иргиз }\end{array}$ & 18 \\
\hline $60-63$ & 103 & Кондурчинская лесостепь & 26 \\
\hline $64-68$ & 102 & Васильевские острова & 2 \\
\hline $64-68$ & 102 & $\begin{array}{l}\text { Дубрава кленово- } \\
\text { ясменниковая }\end{array}$ & 10 \\
\hline $64-68$ & 102 & Балка Лозовая & 18 \\
\hline $64-68$ & 102 & Истоки реки Крымза & 23 \\
\hline $64-68$ & 102 & Урочище Данилин пчельник & 25 \\
\hline $69-70$ & 101 & Урочище Родники & 15 \\
\hline $69-70$ & 101 & Гремячий & 23 \\
\hline $71-72$ & 100 & Игонев дол & 11 \\
\hline $71-72$ & 100 & Истоки реки Б. Вязовка & 15 \\
\hline
\end{tabular}

Эколого-туристический потенциал Самарской области: ресурсы.. (съездов, конференций, совещаний и т.д.) в области изучения и охраны растительного мира.

Таким образом, Самарская область ставит целью развитие внутреннего туризма, что совершенно оправдано. Определенное и не последнее место в этом направлении должен занять экологический туризм, интерес к которому в последнее время значительно возрастает. В экологическом туризме существует незаполненная область, связанная с познавательным и событийным туризмом, ориентированным на растительный мир.

\section{СПИСОК ЛИТЕРАТУРЫ}

1. Саксонов С.В., Сенатор С.А. Путеводитель по Самарской флоре (1851-2011) / Флора Волжского бассейна. Т. 1. Тольятти: Кассандра, 2012. 627 с.

2. Конева Н.В., Саксонов С.В. Реликтовые элементы во флоре Самарской Луки: обзор работ // Экология и география растений и сообществ Среднего Поволжья / под ред. к.б.н. С.А. Сенатора, д.б.н. С.В. Саксонова и чл.-корр. РАН Г.С. Розенберга. Тольятти: Кассандра, 2011. С. 124-131.

3. Саксонов С.В., Сенатор С.А., Конева Н.В. Классификация реликтовых растений центральной части Приволжской возвышенности // Известия Самарского научного центра РАН. 2011. Т. 13. № 5. С. 64-67.

4. Саксонов С.В., Сенатор С.А., Савчук С.С., Рощевский Ю.К. Реликтовые элементы флоры СреднеВолжского биосферного резервата (Приволжская возвышенность) // Экология и география растений и сообществ Среднего Поволжья / под ред. С.А. Сенатора, С.В. Саксонова, Г.С. Розенберга. Тольятти: Кассандра, 2014. C. 342-348.

5. Сенатор С.А., Саксонов С.В. Средне-Волжский биосферный резерват: раритетный флористический комплекс. Тольятти: Кассандра, 2010. 251 с.

6. Васюков В.М., Саксонов С.В., Сенатор С.А. Эндемичные растения бассейна Волги // Фиторазнообразие Восточной Европы. 2015. Т. ІХ, № 3. С. 27-43.

7. Саксонов С.В., Конева Н.В. Некоторые итоги критической ревизии флоры Жигулевской возвышенности: 2. Узколокальные эндемики // Роль особо охраняемых природных территорий в сохранении биоразнообразия и социальном развитии регионов: материалы II республиканской научно-практической конференции (Казань, 23-24 мая 2002 г.). Казань: Отечество, 2003. С. 122-126.

8. Васюков В.М., Саксонов С.В., Раков Н.С., Сенатор С.А. Виды сосудистых растений, описанные с Левобережья Средней Волги // Ботанический журнал. 2015. T. 100, № 4. C. 394-402.

9. Васюков В.М., Сенатор С.А., Раков Н.С., Саксонов С.В. Виды сосудистых растений, описанные с Правобережья Средней Волги // Ботанический журнал. 2015. Т. 100, № 1. С. 44-59.

10. Конева Н.В., Сенатор С.А., Саксонов С.В. Вся Красная книга Самарской области: растения лишайники, грибы. Тольятти: Кассандра, 2009. 272 с.

11. Красная книга Самарской области: Растения / под ред. Г.С. Розенберга и С.В. Саксонова. Тольятти: ИЭВБ РАН, 2007. 372 с. 
12. Симонова Н.И., Соловьева В.В., Митрошенкова А.Е., Саксонов С.В. Редкие мохообразные Самарской области // Известия Самарского научного центра РАН. 2008. Т. 10. №5/1. C. 85-94.

13. Саксонов С.В., Чап Т.Ф. Толокнянковые сосняки Жигулевского заповедника // Изучение и охрана биологического разнообразия природных ландшафтов Русской равнины: сборник материалов Международной научной конференции, посвященной 80-летию Пензенского заповедника (Пенза, 18-19 мая 1999 г.). Пенза, 1999. С. 208-213.

14. Конева Н.В., Саксонов С.В. Низкогорно-скальные сообщества Жигулевского заповедника // Бюллетень ботанического сада Саратовского государственного университета. Вып. 5. Саратов, 2006. С. 120-124.

15. Саксонов С.В., Лысенко Т.М., Ильина В.Н., Конева Н.В., Лобанова А.В., Матвеев В.И., Митрошенкова А.Е., Симонова Н.И., Соловьева В.В., Ужамецкая Е.А., Юрицына Н.А. Зеленая книга Самарской области: редкие и охраняемые растительные сообщества / под ред. чл.-корр. РАН Г.С. Розенберга и докт. биол. наук С.В. Саксонова. Самара: СамНЦ РАН, 2006. $201 \mathrm{c}$.

16. Сенатор С.А. Болота Самарской области - общая характеристика, особенности, заторфованность // Самарская Лука: проблемы региональной и глобальной экологии. 2016. Т. 25, № 4. С. 49-70.

17. Саксонов С.В., Иванова А.В., Ильина В.Н., Раков Н.С., Силаева Т.Б., Соловьева В.В. Флора озера Молочка и его ближайших окрестностей в Самарской области (Высокое Заволжье, Сокский флористический район) // Фиторазнообразие Восточной Европы. 2007. № 2. C. 77-98.

18. Казанцев И.В., Саксонов С.В., Сенатор С.А. Фитосозологическая оценка водно-болотных памятников природы Самарской области // Гидроботаника 2015: материалы VIII Всероссийской конференции с международным участием по водным макрофитам (п. Борок, 16-20 октября 2015 г.) / Федер. агентство науч. орг. России, РАН, ФГБУН Ин-т биологии внутренних вод им. И.Д. Папанина РАН. Ярославль: Филигрань, 2015. С. $125-127$.

19. Казанцев И.В., Саксонов С.В. Фитосозологический рейтинг памятников природы регионального значения Самарской области // Известия Самарского научного центра РАН. 2015. Т. 17. № 4. С. 45-54.

20. Малиновская Е.Н., Розенберг А.Г., Саксонов С.В. Экологический и просветительский потенциал особо охранемых природных территорий Самарской области (на примере памятников природы Сергиевского района) // Инновационные подходы к обеспечению устойчивого развития социо-эколого-экономических систем: материалы международной конференции (19-21 мая 2014 г., Самара-Тольятти). Тольятти: Кассандра, изд-во Самарс. гос. экон. ун-та, 2014. C. $142-146$.

21. Розенберг Г.С., Саксонов С.В., Сенатор С.А., Крючков А.Н. Эколого-туристический потенциал памятников природы регионального значения Самарской области: флористический аспект // Туризм и рекреация: фундаментальные и прикладные исследования. Труды Международной научно-практической конференции. Поволжский гос. ун-т сервиса, 2526 апреля 2013 г. Тольятти, 2013. С. 288-298.

22. Саксонов С.В. Роль памятников природы Самарской области в сохранении редких и исчезающих видов растений // Самарская Лука: Бюл. 2007. Т. 16, № 3(21). С. 503-517.

23. Саксонов С.В., Розенберг А.Г., Сенатор С.А. Фитосозологичесая оценка памятников природы Самарской области // Вестник Самарского государственного экономического университета. Спец. вып. 2014. C. $146-153$.

24. Саксонов С.В., Сенатор С.А. Вклад памятников природы регионального значения в сохранение раритетного комплекса видов Самарской области // Caмарская Лука: проблемы региональной и глобальной экологии. 2012. Т. 21, № 4. С. 34-110.

25. Добровольский Г.В., Розенберг Г.С., Чибилев А.А., Рысин Л.П., Саксонов С.В., Тишков А.А. Ещё раз о природном наследии России // Вестник Российской академии наук. 2005. Т. 75, № 9. С. 787-792.

26. Саксонов С.В. Ключевые ботанические территории Самарской области // Изучение флоры Восточной Европы: достижения и перспективы: Тезисы докладов международной конференции (СПб, 23-28 мая 2005 г.) / под ред. А.Н. Сенникова и Д.В. Гельтмана. М.; СПб: Товарищество научных изданий КМК, 2005. C. 74 .

27. Саксонов С.В., Сенатор С.А. Территории особого природоохранного значения Самарской области // Изумрудная книга Российской Федерации. Территории особого природоохранного значения Европейской России. Предложения по выявлению. Ч. 1. М.: Институт географии РАН, 2011-2013. С. 129-133.

28. Саксонов С.В., Сенатор С.А. История развития ботанических знаний в Самарской области. Тольятти: Кассандра, 2016. 291 с.

29. Сенатор С.А., Саксонов С.В., Ужамецкая Е.А. Растительный покров Тольятти: история изучения // Самарская Лука: проблемы региональной и глобальной экологии. 2013. Т. 22, № 4. С. 191-200.

30. Аншаков Ю.П., Бакиев А.Г., Голубков С.А., Горелов Ю.Н., Дубман Э.Л., Кабытов П.С., Платонов А.И., Розенберг Г.С., Саксонов С.В., Сенатор С.А. Энциклопедия Самарской области: история создания // Самарская Лука: проблемы региональной и глобальной экологии. 2014. Т. 23, № 1. С. 170-191.

31. Саксонов С.В., Сенатор С.А. Раков Н.С. Геоботаническая изученность Средне-Волжского биосферного резервата: история и современность // Отечественная геоботаника: основные вехи и перспективы: материалы Всероссийской научной конференции с международным участием (Санкт-Петербург, 2024.09.2011). Т. 1. Разнообразие типов растительных сообществ и вопросы их охраны. География и картография растительности. История и перспективы геоботанических исследований. Санкт-Петербург, 2011. C. 222-225.

Работа выполнена в рамках программы Отделения биологических наук "Биоресурсы", гранта РФФИ № 14-04-97072 р_поволжье_а и грантов РГНФ № 16-16-63003 a (p), 16-13-63004 a(p). 


\title{
ECOLOGICAL TOURIST POTENTIAL OF SAMARA REGION: FLORA RESOURCES
} (C) 2016

S.V. Saksonov, doctor of biological sciences, professor,

head of Problems of Phytodiversity Laboratory, deputy director for scientific work

A.G. Rozenberg, candidate of biological sciences, junior researcher of Environmental Economics Group

S.A. Senator, candidate of biological sciences, senior researcher of Problems of Phytodiversity Laboratory Institute of Ecology of Volga River Basin of Russian Academy of Sciences, Togliatti (Russia)

I.V. Kazantsev, candidate of biological sciences, dean of Faculty of Natural Sciences and Geography, associate professor of Chemistry, Geography and Methods of Teaching Department

Samara State University of Social Sciences and Education, Samara (Russia)

V.M. Vasjukov, candidate of biological sciences, researcher of Problems of Phytodiversity Laboratory Institute of Ecology of Volga River Basin of Russian Academy of Sciences, Togliatti (Russia)

Abstract. In article development of ecological tourism which, first of all, is based on visit of attractive and unique objects is considered. Flora conforms to these requirements fully.. For the first time 10 bases are formulated which stimulate development of informative ecological tourism (a specific variety, relic types; endemic types; the types described from the territory of the region for the first time for science; the plants recognized protected and included in the Krasnaya kniga; vegetable communities, unique by origin and to structure; zone, typical vegetable communities; places of concentration of plants in the territory of nature sanctuaries; especially valuable natural territories of federal level of protection; key botanical territories) and 5 bases which stimulate development of event ecological tourism (date of birth of researchers; dates of expeditions; dates of the organization of the centers for studying of flora; dates of the publication of the major botanical compositions; dates of the largest scientific forums). Concentration of nature sanctuaries and distribution of especially protected natural territories is described within the Samara Region. In article the generalized criterion for evaluation of the fitosozological status of these territories is used. It is noted that the Samara Region is the perspective territory for development of internal tourism where the important and defining role belongs to ecological tourism.

Keywords: protected areas; nature monuments; ecological tourism; educational tourism; event tourism; species diversity; plant communities; fauna; relics; endemics; rare plants; Red Books; Samara Region.

УДК 504.75.05(470.44)

\section{ОЦЕНКА ВЛИЯНИЯ ИНДЕКСА ЗАГРЯЗНЕНИЯ АТМОСФЕРЫ НА МЕДИКО-ДЕМОГРАФИЧЕСКИЕ ПОКАЗАТЕЛИ ЖИТЕЛЕЙ ГОРОДА САРАТОВА} (C) 2016

\author{
Н.В. Точилкина, старший преподаватель кафедры частного права и экологической безопасности \\ Саратовский соииально-экономический институт \\ Российского экономического университета имени Г.В. Плеханова, Саратов (Россия)
}

\begin{abstract}
Аннотация. В представленной статье рассматривается влияние загрязнения воздуха на демографические характеристики жителей г. Саратова. Описываются основные загрязнители воздуха, оказывающие значительное влияние на заболеваемость неинфекционными заболеваниями, а также на уровень детской смертности. Рассматривается влияние как комплексного показателя уровня загрязнения атмосферы, так и его компонентов на общий уровень смертности, уровень смертности от онкологических заболеваний, от заболеваний органов дыхания и уровень смертности детей до 1 года. Проведенные исследования показали, что существует тесная прямая связь между комплексным показателем загрязнения воздуха и смертностью от заболеваний органов дыхания, а также уровнем детской смертности. Также выявлено, что уровень общей смертности тесно связан с превышением содержания в воздухе оксида азота, уровень смертности от онкологических заболеваний - с превышением содержания оксида азота и фенола, уровень смертности от заболеваний органов дыхания - с превышением содержания формальдегида, уровень смертности детей в возрасте до одного года - с превышением содержания формальдегида и фенола. Несмотря на важность и актуальность подобных исследований, отмечается сложность в доступе к сведениям о заболеваемости по классам заболеваний, по полу и возрасту жителей различных административных районов города. Это не позволяет проводить в полном объеме анализ текущей ситуации и ретроспективные исследования для ее прогнозирования.

Ключевые слова: загрязнение воздуха; комплексный показатель уровня загрязнения атмосферы; уровень общей смертности; уровень смертности от заболеваний органов дыхания; уровень смертности от онкологических заболеваний; уровень смертности детей в возрасте до одного года; г. Саратов.
\end{abstract}

Ежегодно количество горожан увеличивается почти на 70 млн. человек, и весь комплекс городских проблем, связанных как социально-экономической адаптацией населения, так и с оптимизацией его плотности, является одной из характеристик урбоэкосистемы. Экологические проблемы городской жизни многогранны и разноплановы, они могут определяться множеством факторов, однако только удобство и качество жизни горожанина будут интегральной оценкой их решения, правильность которого - высокая продолжительность жизни и низкий уровень заболеваемости. 